MATEC Web of Conferences 47, 04004 (2016)

DOI: $10.1051 /$ matecconf/20164704004

(C) Owned by the authors, published by EDP Sciences, 2016

\title{
Accidents Preventive Practice for High-Rise Construction
}

\author{
Kai Chen Goh ${ }^{1, a}$, Hui Hwang Goh ${ }^{2}$, Mohd Faizal Omar ${ }^{3}$, Tien Choon Toh ${ }^{4}$ and Abdullah Asuhaimi \\ Mohd Zin ${ }^{5}$ \\ ${ }^{1}$ Faculty of Technology Management and Business, Universiti Tun Hussein Onn Malaysia, 86400 Batu Pahat, Johor, \\ Malaysia \\ ${ }^{2}$ Faculty of Electrical and Electronic Engineering, Universiti Tun Hussein Onn Malaysia, 86400 Batu Pahat, Johor, \\ Malaysia \\ ${ }^{3}$ School of Quantitative Sciences, Universiti Utara Malaysia, 06010 Sintok, Kedah, Malaysia \\ ${ }^{4}$ Faculty of Engineering and Science, Universiti Tunku Abdul Rahman, 53300 Kuala Lumpur, Malaysia \\ ${ }^{5}$ Faculty of Electrical Engineering, Universiti Teknologi Malaysia, 81310 Skudai, Johor, Malaysia
}

\begin{abstract}
The demand of high-rise projects continues to grow due to the reducing of usable land area in Klang Valley, Malaysia. The rapidly development of high-rise projects has leaded to the rise of fatalities and accidents. An accident that happened in a construction site can cause serious physical injury. The accidents such as people falling from height and struck by falling object were the most frequent accidents happened in Malaysian construction industry. The continuous growth of high-rise buildings indicates that there is a need of an effective safety and health management. Hence, this research aims to identify the causes of accidents and the ways to prevent accidents that occur at high-rise building construction site. Qualitative method was employed in this research. Interview surveying with safety officers who are involved in highrise building project in Kuala Lumpur were conducted in this research. Accidents were caused by man-made factors, environment factors or machinery factors. The accidents prevention methods were provide sufficient Personal Protective Equipment (PPE), have a good housekeeping, execute safety inspection, provide safety training and execute accidents investigation. In the meanwhile, interviewees have suggested the new prevention methods that were develop a proper site layout planning and de-merit and merit system among subcontractors, suppliers and even employees regarding safety at workplace matters. This research helps in explaining the causes of accidents and identifying area where prevention action should be implemented, so that workers and top management will increase awareness in preventing site accidents.
\end{abstract}

\section{Introduction}

Construction site is a work place which exist a lot of hazardous activities and accidents [1]. The safety and health issues in construction industry need to be pay more attention due to the frequently development of high rise building in the country. Every year, a high number of accidents were happen at building construction site especially at the high rise building construction site [2]. Many of the unpredictable hazards and accidents are available at the construction site and thousands of workers were injured and killed in every year [3]. The most common accidents at high-rise building

\footnotetext{
${ }^{\text {a }}$ Corresponding author : kaichen@uthm.edu.my
} 
construction site are workers fall from height and injuries caused by fallen objects [3]. According to the National Fire Incident Reporting System (NFIRS), high rise building can be classified into four ranges which are 7-12 stories 13-24 stories, 25-49 stories, and 50 stories or more [4]. In general, 75 feet (23 meter) or seven stories will be the cut-off point for the most purpose [4]. In year 2011, 4,937 cases of accidents were reported in the construction industry and it was the second highest record of accidents reported among all the industries [5]. In the same year, there are total 9,057 cases of people falling from height accidents and 4,689 cases of struck by falling object accidents occurred [5]. The figures, which are based on the statistics of Social Security Organization, are considered high when compared to the amount of the existing workforce in Malaysia. This study is focus to identify the causes of accidents at high-rise building construction site and to identify the preventive measures for accidents at high-rise building construction site. Besides that, this research helps in explaining the causes of accidents and identifying area where prevention action should be implemented, so that workers and top management will increase awareness in preventing site accidents.

\section{Literature Review}

There are four types of high-rise accidents, which are by scaffolding, people fall from height, struck by falling object and plant and machinery. The workers are always exposed to the risk of collapse of the scaffolding. Major of the scaffold accidents occurred were due to the use of defective materials for scaffolding and coupled with the unskilled and careless workmanship in erection of scaffolds [6]. In construction industry, falls is not only the most fatal accidents but it also is the most frequent occurred accidents $[7,8]$. Everybody in the construction site has the risk to expose to fall in anywhere and anytime especially at the higher level [9]. In general, lack of the safety measure at the construction sites is one of the causes the occurrence of fall accidents [2]. Struck by falling object accidents can be defined as people who work at construction site is struck by the equipment, private vehicles, falling materials, vertically hoisted materials and horizontally transported materials [7]. The improper rigging method had caused the accident happen [10]. Overloading is one of the factors that will cause the cranes collapse in the high-rise building construction. During the operation, the amount of allowable handling load by the crane is always not proper control by the supervisor [11]

Accident is an event of unpredictable and it may occur due to the following causes, lack of training, improper equipment and working platform, wrong safety attitude, inadequate housekeeping, failure to use personal protective equipment (PPE), and problem procurement method and subcontracting method. The lack of training can caused accidents at construction site [12]. Because of the lack of training in safety and technology knowledge, workers are haven't ability and sufficient knowledge to predicts the potential risk and the way to avoid the accidents [13]. The use of unsafe working platforms also may put workers at risk when the equipment is not properly used, maintained or stored [14]. Construction worker's safety attitude is influence by their understanding and realizing of risk, management, safety rules and the working procedures [15]. The unsafe actions are include do not follow the standard safety procedures, constructing barbarously and deciding to proceed work in an unsafe conditions. [13]. The poor housekeeping in the workplace can be considered as a risk factor for occupational injuries [16]. Working without wearing any PPE may highly increase the probability for occurrence of any undesired accident. The various reason of workers refuse to wear PPE during working are such as feel uncomfortable with the gears while performing their job at site and consider it as an disturbing item to their work output. According to Ali, et al. [17], the International Labour Organization has revealed that some of the workers felt uncomfortable while wearing any types of PPE and it indirectly decreases their work performance. Sub-contractors usually have poor safety awareness at the construction site. Poor coordination, lack of proper instructions and misunderstanding between working trades all can lead to construction accidents [13].

According to Occupational Safety and Health Act 1994, section 24 [18], the employees are responsible to wear or use at all the times of any protective equipment or clothing which provided by the employer. Good housekeeping is the best defenses against accidents during construction [19]. Therefore, good housekeeping is an important part in any construction site which help to reduce 
occurrence of accidents and improve the overall safety performance [20]. Inspection is one of the common forms of analysis to prevent any accidents. . Inspections are part of a preventive or proactive to accident prevention [19]. Training is a necessary and important part of accident prevention policy [21]. Training is a necessary and important part of accident prevention policy [21]. Each of the company should ensure that the training program is an integral part of the instruction given to all men in construction work and make sure them particular attention towards to the safety issues [19]. The nature of the construction industry's rapidly changing conditions, associated work hazards, and the characteristics of construction organizations further aggravate the situation [22]. Therefore, there are necessary to implement the appropriate prevention action to prevent the occurrence accidents effectively.

\section{Methodology}

This research is conducted by qualitative methods only. Data which collect from the primary source which are semi-interview were analyzed with the exploratory data analysis method According to Silverman [23], the important most things in the method of qualitative analysis are focused in the documents, transcripts, diagrams and text that make up the data. This research is choosing to adopt qualitative content analysis method. Content analysis involves establishing categories and then counting the number of instance when those categories are used in the particular item of text. Matrix table is used to assists in analyzing the interview information data. The collected data were analyzed at next stage to rearrange the data in form of easy to understand and clear to read. Discussion has been done to determine the research objectives successfully achieved. At the end of research, recommendation and conclusion were developed.

\section{Data Analysis and Discussion}

The findings presented in the research provide basic and justification for the conclusion to be drawn in the study. Therefore the findings have to be meticulously analyzed and explained in a logical organized manner. Using tables for the data display analyze the obtained data. The data were divided into three sections. Table 1 is about the perception of interviewees on the types of at high rise building construction site, Table 2 is about the perception of interviewees on the causes of accidents at high rise building construction site and Table 3 is about ways to prevent accidents at high rise building construction site. Semi-structured interviews were carried out with safety officers who were involved in different types of high-rise building projects in Malaysia. There are 7 interviewees who come from 3 companies involved in this semi-structured interview. They are involved in different types of highrise buildings, which consist of services apartments, office blocks and condominiums.

Table 1. Perception of types of accidents at high-rise building construction site.

\begin{tabular}{ll}
\hline \multicolumn{1}{c}{ Perception } & \multicolumn{1}{c}{ Annotations } \\
\hline - & $\begin{array}{l}\text { "Workers are less awareness that they are working at high condition and common } \\
\text { Personal Protective Equipment (PPE) not sufficient provided or equipped } \\
\text { properly. Besides that, unsafe workplace condition that caused by poor } \\
\text { housekeeping will cause workers slip and falling from height. In addition, poor } \\
\text { housekeeping also will cause workers hit by falling working tools." (R1, R2, R3 } \\
\text { and R5) } \\
\text { "There is not enough guidance for workers regarding the safety matters at } \\
\text { construction site." (R4) } \\
\text { "Government rules and regulations are not enough strong to control the safety and } \\
\text { falling } \\
\text { object/working } \\
\text { tool }\end{array}$ \\
\hline
\end{tabular}


From the results on the collected data from interview with 7 safety officers who conducted different projects on high rise building in Kuala Lumpur, all the interviewees have the same perception that the most frequently happened accidents at high rise building construction site were people falling from height accidents and accidents due to struck by falling object or working tools. According to the above annotation the highest accidents that occur at construction site in Malaysia are workers falling from height followed by accidents due to struck by object falling from height. Therefore, according to the past report and the existing interview collected data prove that the most frequently occurred accidents at high rise building construction site in Malaysia is people falling from height followed by accidents due to struck by object falling from height.

Table 2. Perceptions of major causes of accidents at high rise building construction site.

\begin{tabular}{|c|l|c|c|c|c|c|c|c|}
\hline \multicolumn{1}{|c|}{ Question } & \multicolumn{1}{|c|}{ Perception } & R1 & R2 & R3 & R4 & R5 & R6 & R7 \\
\hline \multirow{5}{*}{ Major causes of accidents } & Unsafe acts (workers' attitude) & $\sqrt{ }$ & & $\sqrt{ }$ & & & $\sqrt{ }$ & \\
\hline & Unsafe condition (poor housekeeping) & $\sqrt{ }$ & & & & & $\sqrt{ }$ & \\
\hline & Unskilled workers & & $\sqrt{ }$ & & $\sqrt{ }$ & $\sqrt{ }$ & & \\
\hline & Lack of training & & $\sqrt{ }$ & & $\sqrt{ }$ & & $\sqrt{ }$ & $\sqrt{ }$ \\
\hline & Poor site safety management & & $\sqrt{ }$ & & & & & $\sqrt{ }$ \\
\hline & Cost saving & & & $\sqrt{ }$ & $\sqrt{ }$ & & & \\
\hline & Less awareness of hazardous activity & & & & & $\sqrt{ }$ & & $\sqrt{ }$ \\
\hline
\end{tabular}

Different perception of interviewees regard the major causes of accident were due to the unsafe acts at construction site. Worker's unsafe acts are always due to operating machinery without qualification or authorization, horseplay, operating equipment at unsafe speed and lack of or improper use of Personal Protective Equipment (PPE). According to R1, R2 and R6, they believe that worker's unsafe acts caused unsafe condition exists at construction site. Generally, unsafe condition is a condition in the workplace that is likely to cause property damage or injury. Unsafe condition is normally due to poor housekeeping, defective tools and equipment and congestion in the workplace. "Most of the occurred accidents were due to workers who lack training. Their safety knowledge and working skill are not sufficient in handling their task. (R2, R4, R6, R7). According to the experiences of the interviewees, most of them agree that worker who lacks training is one of the major causes of accidents which occurred at high rise building construction site. Workers who lack training or unskilled workers had not been enough qualification to operate certain machinery or working tools, therefore unsafe condition workplace do exists. Besides that R2 and R7 stated that not only worker who lack training is the major cause but also the poor site safety management. Safety officer and project team who do not have safety awareness will cause poor site safety management available whereas R5 and R7 agree that both employees and employer are less awareness of hazardous activities which exist anytime at the construction site. ".....and some contractors are trying to save project cost in providing sufficient PPE and training for the workers." (R3 and R4). Other than that, R3 and R4 do experience that one of the major causes of accidents at high rise building construction site is cost saving by employer. The cost for preparing safety training and PPE are extremely expensive, therefore safety training and PPE might insufficient provided. The causes of accident at high rise building construction site not only due to lack of training, improper equipment and working platform, wrong safety attitude and inadequate housekeeping but also caused by cost saving by contractor, poor site safety management and less awareness of hazardous activities workers and employers.

All the interviewees have been implemented several alike of accidents prevention methods that were provided regular training to workers regarding safety awareness at construction site, accidents investigation and safety inspection. Besides that, interviewees from company A's also implemented accidents prevention method by giving instrument for new workers, daily toolbox, safety introduction awareness campaign and having site monthly meeting to follow up the safety matters at construction site. According to R5, they not only implemented the above prevention method but also implemented by providing regular training to management level and supervision team regarding safety awareness at 
construction site. Besides that, R7 also have been implement site monthly meeting to prevent any unsafe act and unsafe condition at construction site.

Table 3. Type of accidents prevention methods used by company.

\begin{tabular}{|c|c|}
\hline Type of used prevention method & Annotations \\
\hline $\begin{array}{l}\text { Regular training to workers regarding safety } \\
\text { awareness at construction site } \\
\text { Accidents investigation } \\
\text { Safety Inspection }\end{array}$ & $\begin{array}{l}\text { - } \quad \text { Basically we are providing regular training to workers } \\
\text { regarding safety awareness at construction site, execute } \\
\text { accident investigation and implement safety inspection." } \\
\text { (All interviewees) }\end{array}$ \\
\hline $\begin{array}{l}\text { Instrument for new workers } \\
\text { Daily toolbox } \\
\text { Regular training to management level and } \\
\text { supervision team regarding safety awareness } \\
\text { at construction site } \\
\text { Safety introduction awareness and campaign } \\
\text { Site monthly meeting }\end{array}$ & $\begin{array}{l}\text { - In addition, our company also provide instrument for } \\
\text { new workers, implement daily toolbox checking, regular } \\
\text { training to management level and supervision team } \\
\text { regarding safety awareness at construction site, safety." } \\
\text { introduction awareness campaign site monthly meeting." } \\
\text { (R1, R2 and R3) } \\
\text { "Not only training for workers but also to management } \\
\text { level and supervision team." (R5) } \\
\text { "In controlling the safety matters, we are having meeting } \\
\text { every end of the month." }\end{array}$ \\
\hline
\end{tabular}

\section{Conclusion}

This study has provided an overview on the causes of accidents and preventive measures at high-rise building construction site. The causes of accidents at high rise building were due to workers lack of training, unskilled workers, workers unsafe acts, unsafe condition, poor site safety management and less awareness of hazardous activities at work site. In addition, implement de-merit and merit system among sub-contractors, suppliers and even employees regarding safety at workplace matters and develop a proper site layout planning as one of the prevention method at high rise building construction site. As a summary, although some preventive measures have been result in the reduction of the number of accidents, but there is still no room for satisfying in view of high fatality. In addition further research should focus on the audition and inspection of safety at construction site to ensure the effectiveness of accidents prevention methods during project operation. Therefore, it is important that all parties to cooperate to implement the preventive measures in dealing with safety matters at highrise building construction site.

\section{Acknowledgment}

The authors express gratefully acknowledgment to the industry stakeholders for their valuable contributions towards the success of this research. This research is fully funded by Universiti Tun Hussein Onn Malaysia (UTHM) and Ministry of Higher Education (MOHE) under Vot: 1521, FRGS on Flood Disaster Management 2015 and Vot 1445, Research Acculturation Collaborative Effort (RACE) Phase 2/2013.

\section{References}

[1] T. Dejus, Accidents on construction sites and their reasons, Proc. of the 9th International Conference: Modern Building Materials, Structures and Techniques, 241-247, (2008). 
[2] F.K. Wong, A.P. Chan, M.C. Yam, E.Y. Wong, T. Kenny and K.K. Yip, Findings from a research study of construction safety in Hong Kong: Accidents related to fall of person from height, Journal of Engineering, Design and Technology, 7, 130-142, (2009).

[3] O. Murty, B. Chung, L. Yin and T. Loo, Pattern of injuries in fatal accidents of construction workers: A retrospective study of 10 years (1996-2005), The Malaysian Journal of Forensic Pathology and Science, 44, (2006).

[4] J. R. Hall, High-Rise Building Fires, One-Stop Data Shop, Quincy, Massachusetts, (2005).

[5] Social Security Organisation, Anual Report 2011, Social Security Organisation Malaysia, (2011).

[6] J.C. Rubio-Romero, M. Rubio and C. García-Hernández, Analysis of construction equipment safety in temporary work at height, Journal of Construction Engineering and Management, (2012).

[7] J. Hinze, X. Huang and L. Terry, The nature of struck-by accidents, Journal of Construction Engineering and Management, 131, 262-268, (2005).

[8] D. Zhou and Q. Pang, Study on prevention measures of falling accidents during construction, ICPTT 2012, 1494-1501, (2012).

[9] Y.H. Lin and C.Y. Chen, Statistical analysis of fatal occupational falls in the Taiwan construction industry from 1996-2007, Proc. of the 40th International Conference on Computers and Industrial Engineering, 1-4, (2010).

$[10] \mathrm{W}$. Wu, H. Yang, Q. Li and D. Chew, An integrated information management model for proactive prevention of struck-by-falling-object accidents on construction sites, Automation in Construction, 34, 67-74, (2013).

[11]D.J. Edwards and G.D. Holt, Case study analysis of construction excavator H\&S overturn incidents, Engineering, Construction and Architectural Management, 17, 493-511, (2010).

[12] A. Gibb, S. Hide, R. Haslam, S. Hastings, A. Suraji and A. Duff, Identifying root causes of construction accidents, Journal of Construction Engineering and Management, 127, 348-349, (2001).

[13]Z. Chen and Y. Wu, Explaining the causes of construction accidents and recommended solutions, Proc. of the International Conference on Management and Service Science, 1-5, (2010).

[14]S. Chi, S. Han, and D. Kim, The relationship between unsafe working conditions and workers' behavior and their impacts on injury severity in the U.S. Construction Industry, Journal of Construction Engineering and Management, (2012).

[15]S. Mohamed, T.H. Ali and W.Y.V. Tam, National culture and safe work behaviour of construction workers in Pakistan, Safety Science, 47, 29-35, (2009).

[16] V.M. Dufort and C. Infante-Rivard, Housekeeping and safety: An epidemiological review, Safety Science, 28, 127-138, (2001).

[17]A. Ali, S. Kamaruzzaman and G. Sing, A Study on causes of accident and prevention in Malaysian construction industry, Journal of Design + Built, 3, 95-104, (2010).

[18] Occupational Safety and Health Act 1994, 514, (2002).

[19]P. Hughes and E. Fereett, Introduction to Health and Safety in Construction, Elsevier, United Kingdom, (2007).

[20]N.V. Schwatka, L.M. Butler and J.R. Rosecrance, An aging workforce and injury in the construction industry, Epidemiologic Reviews, 4, 156-167, (2012).

[21]B. Hare and I. Cameron, Site manager safety training, Engineering, Construction and Architectural Management, 18, 568-578, (2011).

[22]R.M. Choudhry and D. Fang, Why operatives engage in unsafe work behavior: Investigating factors on construction sites, Safety Science, 46, 566-584, (2008).

[23]D. Silverman, David Silverman Interpreting Qualitative Data, SAGE, India, (2011). 